\title{
Antibacterial Coating of Implants
}

\author{
Fehim Findik* \\ Sakarya Applied Science University, Turkey
}

Submission: January 16, 2019; Published: February 26, 2019

*Corresponding author: Fehim Findik, BIMAS-RC, Sakarya Applied Science University, Sakarya, 54187, Turkey

Keywords: Biomaterials; Antibacterial; Implant; Titanium; Adverse effects

\section{Introduction}

Biomaterials are biological or artificial elements designed to perform, improve or replace the normal tasks of unique tissues, depending on the biological system. The best biomaterial properties vary depending on the substituted tissue and the required function. Many researchers have focused on "the development of effective antibacterial surfaces that prevent bacterial adhesion" and spread to nearby tissues [1]. The purpose of this mini-review is to summarize the current knowledge in this area, its stress on technologies suitable for inhibiting joint infection in total joint arthroplasty. Related technologies may be involved in predicting surgical infections in additional orthopedic conditions related to implants, such as plates and external fixators.

\section{Perspectives of Antibacterial Modification}

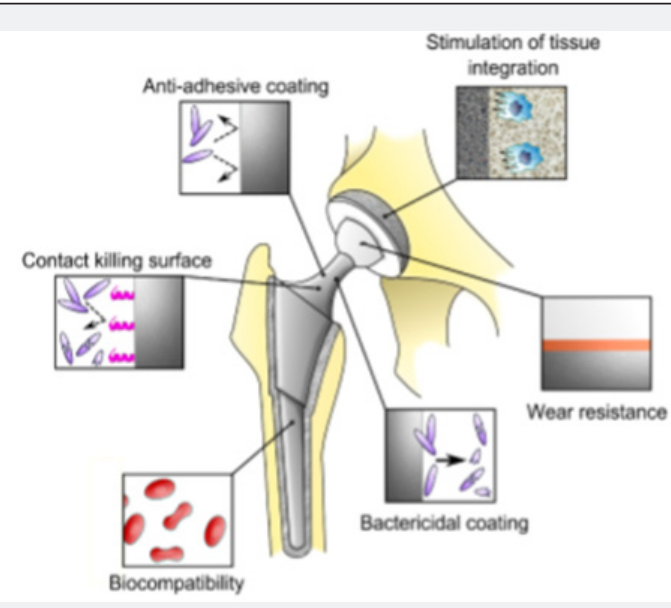

Figure 1: "Multifunctional surfaces in hip arthroplasty designed to respond to various biological and mechanical tasks" [2]..

Numerous principles have been proposed from basic research to transform orthopedic implants into technologies appropriate for the antibacterial effect. It is easy to distinguish between technologies that offer anti-adhesion properties, those who work as antimicrobial agents, and those that combine the attitudes mentioned above. Anti-infective surfaces can be categorized by as "contact killing" and by eluting the antimicrobial agent [2]. The coatings may also be degradable and non-degradable. In terms of functionality, the surfaces can be separated as single-function and multi-functional. The second is expected to target several biological tasks at the same time (Figure 1). A "smart surface" is a completely different method designed as a self-responding, multitasking micro machine that removes antimicrobial materials after being inspired by microbiological indications.

\section{Titanium Surface Antibacterial Modification}

A wide variety of materials are used as biomaterials; however, we will focus on the surface modification of titanium in this mini-review. Ti and its alloys (adding V, Fe and $\mathrm{Nb}$ into Ti$6 \mathrm{Al}$ alloy) are one of the most commonly used materials for both trauma and elective applications in orthopedics. Ti has better corrosion resistance, high strength, low density and elastic modulus than other metals. The advantage of using Ti-based alloys is that they are not reactive due to automatic passivation. Conversely, the bioinert structure of $\mathrm{Ti}$ also means that it does not exhibit osteoinduction as a flat surface. Titanium is a very compatible material, and many methods have been used to connect the porous architecture to adapt surface roughness and support osseointegration. Common micro-scale surface modification methods for enhanced osseointegration can be separated into surface roughening (e.g., plasma spray, etching and anodising) and surface coating (e.g., hydroxyapatite (HA) coating). Presently marketed implants include a porous coating; plasma spray HA coating; HA coated plasma spray HA coated sintered titanium beads on porous plasma spray titanium alloy. Clinical studies have shown good clinical results and prosthetic persistence with uncontaminated fixation [3]. However, the 
effect of macro-micro-surface roughness on bone growth is insufficient [4]. Many of these methods produce bone growth due to wear and deterioration on the surface due to poor attachment between the surface layer and underlying implant, rather than allowing growth and bone growth [5]. In addition, the effect of these surface changes on bacterial adhesion and biofilm formation was investigated.

\section{Adverse effects of surface modification}

The wear particles from both the bed and the implant materials may be limited and have universal implications. Wear particles are found in the "liver, spleen and lymph nodes and silver nanoparticles" are recognized in brain astrocytes [6]. Wearing polyethylene wear particles are one of the main causes of periprosthetic osteolysis which causes the release and failure of the implant. "Particle size plays an important role in defining the cellular reaction". "Particle sizes greater than 500nm tend to be immersed by professional phagocytes with an actindependent mechanism [7], but small particles are endocytosis by non-professional phagocytic cells". Ti wear particles (1.5$4 \mu \mathrm{m}$ ) have adverse effects on osteoblast spread and feasibility, convincing fibroblasts to increase the activity of MMP2 and 9, which causes the release of matrix metalloproteinases (MMP) in osteolysis and decreases bone development. Micrometric Ti particles reduced Saos-2 adhesion strength, migration and diffusion. In addition, Ti wear particles induce the production of inflammatory cytokines, induce lymphocytes to initiate an immune reaction and increase vascular endothelial growth factor expression [8].

"Ti dioxide (TiO2) is widely used for nanoscale surface modification"; however, TiO2-specific nanoparticles may have opposing effects. It has been shown that $\mathrm{TiO} 2$ nanoparticles are distributed to the heart, lung and liver, and can pass through the placenta [9]. It has been shown in a mouse model that it is transferred to offspring and affects the cranial nervous system, has a large number of "immunomodulatory effects and may be associated with genotoxicity" [10]. "In the local setting, TiO2 nanoparticles have been shown to adversely affect cell migration and MSC differentiation in rats". In contrast, no longterm clinical trial showed any hostile effect on the distribution of TiO2 particles.

\section{Conclusion}

Inhibition is the best response to the increasing problem of orthopedic implant infections. The work in the field of antibacterial surface treatment has emerged in numerous skilled technologies. Bacterial adhesion and a little delay in the early stages of biofilm development. Others have smooth antibacterial properties. Policies involving nanotechnologies have created numerous potentials. Potentially, multifunctional smart surfaces can open up new ways to prevent bacterial adhesion but can also open new paths for the healing and restoration of tissue homeostasis.

\section{References}

1. Cats-Baril W, Gehrke T, Huff K, Kendoff D, Maltenfort M, et al. (2013) International consensus on periprosthetic joint infection: Description of the consensus process. Clin Orthop Relat Res 471(12): 4065-4075.

2. Zaborowska M, Welch K, Branemark R, Khalilpour P, Engqvist H, et al. (2014) Bacteria-material surface interactions: Methodological development for the assessment of implant surface induced antibacterial effects. J Biomed Mater Res B Appl Biomater 103(1): 179187.

3. Wyatt M, Hooper G, Frampton C, Rothwell A (2014) Survival outcomes of cemented compared to uncemented stems in primary total hip replacement. World J Orthop 5(5): 591-596.

4. Vercaigne S, Wolke JG, Naert I, Jansen JA (1998) The effect of titanium plasma-sprayed implants on trabecular bone healing in the goat. Biomaterials 19(11-12): 1093-1099.

5. Chung CJ, Long HY (2011) Systematic strontium substitution in hydroxyapatite coatings on titanium via micro-arc treatment and their osteoblast/osteoclast responses. Acta Biomater 7(11): 4081-4087.

6. Luther EM, Koehler Y, Diendorf J, Epple M, Dringen R (2011) Accumulation of silver nanoparticles by cultured primary brain astrocytes. Nanotechnology 22(37): 375101.

7. Aderem A, Underhill DM (1999) Mechanisms of phagocytosis in macrophages. Annu Rev Immunol 17: 593-623.

8. Miyanishi K, Trindade MCD, Ma T, Goodman SB, Schurman DJ, et al (2003) Periprosthetic osteolysis: induction of vascular endothelial growth factor from human monocyte/macrophages by orthopaedic biomaterial particles. J Bone Miner Res 18(9): 1573-1583.

9. Wang JX, Fan YB, Gao Y, Hu QH, Wang TC (2009) TiO2 nanoparticles translocation and potential toxicological effect in rats after intraarticular injection. Biomaterials 30(27): 4590-4600.

10. Lappas CM (2015) The immunomodulatory effects of titanium dioxide and silver nanoparticles. Food Chem Toxicol 2015; 85: 78-83. 
This work is licensed under Creative Commons Attribution 4.0 License

DOI: 10.19080/CTBEB.2019.18.555990
Your next submission with Juniper Publishers will reach you the below assets

- Quality Editorial service

- Swift Peer Review

- Reprints availability

- E-prints Service

- Manuscript Podcast for convenient understanding

- Global attainment for your research

- Manuscript accessibility in different formats

( Pdf, E-pub, Full Text, Audio)

- Unceasing customer service

Track the below URL for one-step submission https://juniperpublishers.com/online-submission.php 